\title{
Brigands and Brigadiers: The Problem of Banditry and the Military in Nineteenth- Century Greece
}

\author{
By Nicholas C. J. Pappas*
}

Before the evolution of modern standing armies of Europe in the 17th and 18th centuries, the recruitment and conduct of military units usually depended on their commanders. These officers were often charged by authorities to recruit, train, maintain and command a body of men in return for a lump sum or contract for a set amount of time. Formations, from company to regiment, often became proprietary, and could be purchased, inherited, and sold. The lack of employment in the military sphere would often lead these free companies and their leaders into brigandage. The establishment of effective state bureaucracies and armed forces that could pay, supply, train and discipline troops without the use of private contractors brought about the decline of free mercenary companies in Europe by the 18th century. However, irregular units under their own commanders continued in the Balkans, and in this case Greece, continued into the 20th century. Irregular forces played the predominant role in the Greek Revolution, 1821-1830, but the subsequent flawed policy of forming a regular army, in which half were foreigners, led to both an increase of banditry and to political/military turmoil. This essay is to investigate brigandage in 19th century Greece and its relationship with the mobilization, maintenance, and demobilization of the armed forces (especially irregular bands). It will also study how the irregulars were both used in irredentist movements and pursued as bandits. This syndrome only ended with the formation of effective armed forces and gendarmerie.

\section{Introduction}

Anyone studying military history with a view beyond generals, battles and institutions finds instances where violence sanctioned by states in the form of military campaigns reverts into criminal activity. Indeed, it is hard to say whether these instances are exceptions or the rule. In the twentieth century, the conducts of some states and their armed forces have come to be seen in judicial terms as war crimes, especially in the case of the systematic persecution and/or destruction of civilian populations. Every war in history has seen soldiers involved in what would in be considered criminal activity, be it murder, rape, robbery, extortion, or black-marketeering, some actions being blessed with official recognition of political/military authorities, others not. The development of military tribunals and military police are an indication of the modern state's concern in controlling the behavior of its military ${ }^{1}$.

The unsanctioned use of organized armed force, known as brigandage

${ }^{*}$ Professor of History, Sam Houston University, USA.

1. A Corvisier, Armies and Societies in Europe, 1494-1789, tr. A. T. Siddall (Bloomington, IN: Indiana University Press, 1979), 78. 
or banditry, has been inextricably linked to armies and navies since time immemorial, and has not been effectively controlled by military justice or military police. The distinction between mercenary company and brigand band, between privateer and pirate, was quite minimal in warfare up until the development of modern armies, and remains minimal in many areas of the world today, especially with the rise of irregular warfare in the form of the guerrilla. In every war and in every armed force, the circumstances of recruitment, service and demobilization, have often led military men, both as individuals and as units, to engage in activities that would be considered criminal. For example during the Thirty Years War of the 17th century, central Europe was devastated by the depredations of unemployed mercenary companies. The picaresque novel of the era, Simplicius Simplicissimus, described these mercenaries in this manner ${ }^{2}$ :

For gluttony and drunkeness, hunger and thirst, whoring and sodomy, gambling and dicing, murdering and being murdered, slaying and being slain, torturing and being torturied, pursuing and being pursued, frightening and being frightened, robbing and being robbed, looting and being looted, terrorizing and being terrorized, mortifying and being mortified, beating and being beaten, in short, nothing but hurting and harming and being, in their turn, hurt and harmed, this was their whole purpose of existence.

Until the development of modern standing armies of Europe in the seventeenth and eighteenth centuries, the behavior of military units often depended on their immediate commanders. Authorities mostly commissioned these commanders to recruit, train, maintain and command a body of men in return for a lump sum or contract. Units, from company to regiment, often became proprietary, which could be purchased, inherited, and sold. The lack of employment in the military sphere would often lead these free companies and their commanders into brigandage ${ }^{3}$. The establishment of effective state bureaucracies and armed forces that could pay, supply, train and discipline troops without the use of independent contractors brought about the end of free mercenary companies in Europe by the eighteenth century. However outside of Western Europe, the mercenary/bandit syndrome continued, as in the Ottoman Empire and the emergent Balkan states, such as Greece. This problem of the military and banditry came into higher relief in the Near East because the modern European armies existed in a stark comparison ${ }^{4}$.

The purpose of this essay is to investigate banditry in 19th century Greece and its relationship with the mobilization, maintenance, and demobilization of the armed forces (especially irregular bands). Bandit activity in the Greek countryside seems to have increased after each of the numerous armed conflicts

2. H.J.C. Grimmelshausen, The Adventures of a Simpleton, tr. Walter Wallich (New York: Ungar, 1963), 27

3. W. H. McNeill, The Pursuit of Power: Technology, Armed Force and Society Since A.D. 100 (Chicago: University of Chicago Press, 1982), 102-117.

4. H. Inalcik, "The Socio-Political Effects of the Diffusion of Firearms in the Middle East," in War, Technology and Society in the Middle East, ed. V. J. Parry and M. E. Yapp (London. Oxford University, 1975),193-227, 1-89. 
and international crises of the newly independent country in the nineteenth century. This study will look into why banditry flourished in these periods; what was the social composition and military background of the bandits; and how the bandits operated and maintained themselves. It will investigate the problems that the Greek government encountered in controlling the mobilization, maintenance and demobilization of its armed forces, and in developing an effective gendarme corps (chorophylake) to control the problem of banditry.

Probably John Koliopoulos has written the most important studies on the problem of banditry in Greece in the nineteenth century. He has presented a number of studies in essay and book form based upon a wealth of primary sources. This study will probably not add any new information that has not been covered by Koliopoulos' works, but will address certain problems raised by him from a different perspective(see works by Koliopoulos in references).

\section{Modern Greece, Irredentism, and the Army}

During the nineteenth century, the concept that preoccupied much of Greek domestic politics and foreign policy on both an official and unofficial level was the form of irredentism known as the "Megali Idea" or Great Idea. It can be best described by the words of its instigator and main proponent in the early nineteenth century, Ioannes Kolletes ${ }^{5}$ :

The Kingdom of Greece is not Greece; it is merely a part, the smallest and poorest, part of Greece. The Greek is not only he who lives in the Kingdom, but also he who lives in Ioannina or Thessalonike, Serres or Adrianople or Constantinople or Trebizond or Crete or Samos or any other region belonging to Greek history or to the Greek race.

It would be assumed that Greek aspirations in the Balkans, Asia Minor and the insular Mediterranean would have had as one of their main instruments a strong and efficient army to back them up in the diplomatic arena. Nevertheless, throughout the nineteenth century, Greece had a small, generally inefficient army whose record was far from noteworthy. The territorial growth of the Greek state from its independence up to the Balkan Wars was brought about not by military successes of the Greek state, but rather by the struggles and tenacity of the irregular bands of the unredeemed Greece and the diplomatic machinations of the Great Powers. A major factor in Greece's inability to act independently in its foreign goals was that it was hamstrung by the major powers since its inception as a Kingdom. As early as the Treaty of London (1830), a tripartite protectorate consisting of Britain, France, and Russia was established over Greece.

The control of the Powers was maintained in various methods, one of the chief being the use of loans to have a binding influence over Greek finances,

5. S. Markezines, Politike Historia tes Neoteras Hellados. v. 1. Athens: Papyros, 1966), 208. 
which would, in turn, affect the establishment and maintenance of the armed forces. For example, in 1832, the Powers financed the imposition of German troops over native Greek forces through the guaranteed loan of that year ${ }^{6}$. Likewise, over sixty years later, the financial controls put upon Greece by the Powers after the 1897 war hampered the recovery and growth of the Greek armed forces for over a decade.

In their management of the Eastern Crises, the Powers, particularly Great Britain and France, interfered directly to prevent Greek involvement. During the Crimean War, for example, Greece was occupied by a naval force and was coerced into neutrality. Thirty years later, when Greece mobilized as a result of the Bulgarian annexation of Eastern Rumelia, the Britain and other powers (with France abstaining) placed it, a country dependent upon commerce, under blockade? .

The Powers often overlooked Greece in their diplomacy, because they believed that the quasi-independent kingdom could be controlled. For example, during the crisis arising from the Cretan insurrection of 1866-1868, they did not allow Greece to attend a Paris conference for its settlement and the conference obliged Greece to accept a Turkish ultimatum that it had previously rejected. In their actions, however, the Powers were expressing their assessment of the ability of the Greek Kingdom to reinforce its aspirations and claims with armed force.

Their low estimation of the Greek army for the most part was justified. Up until the Balkan Wars, the Greek army never reached over 30,000 men in numerical peacetime strength, about 80,000 men at a wartime footing. ${ }^{8}$ Organizationally, the force was divided into battalions; during the RussoTurkish war and Eastern Crisis of 1878-1880, the regimental units were initiated. It was not until the Greco-Turkish War of 1897, that the army was organized along divisional lines and that only in time of war ${ }^{9}$. Furthermore, the weaponry and technical aspects of the Greek army remained behind that of the rest of Europe and the Ottoman Empire during most of its existence until the Balkan Wars.

One basic reason for this weakness in the Greek army in these areas was that the resources of Greece in manpower and finances were limited. Greece's population did not exceed one million until the 1860s and only attained the figure of two million after the acquisition of Thessaly in 1881. Furthermore, at the turn of the century, emigration to the United States began seriously to affect Greece's military manpower needs. In certain areas, up to two-thirds of those eligible for army service were abroad. This problem affected Greece more than

6. K. Mendelssohn-Bartholdy, Geschichte Griechenlands von der Eberung Konstantinopels durch die Türken in Jahre 1453 bis auf unsere Tage, [History of Greece from the conquest of Constantinople by the Turks in 1453 to our days], v. 2. (Leipzig: Verlag von G. Hirzel, 1874), 9.

7. N. Pappas, "Greece and the Russian- Ottoman War of 1877-1878," in OttomanRussian War of 1877-1878 (Ankara: Middle East Technical University Press, 2006).

8. Genikon Epiteleion Stratou. Dieuthynsis Historias Stratou, Historia tes Organoseos tou Hellenikou Stratou 1821-1954 (Athens: Dieuthynsis Historias Stratou, 1957), 29, 33, 36, 42, 47, 62, 66, 72, 84 .

9. Ibid., 53-54. 
it did the other Balkan states, since among Bulgarians, Romanians, and Serbs; it was mostly those living under Turkish or Austrian authority that emigrated, while Greeks of the Kingdom made up a large part of Hellenic emigration. ${ }^{10}$

The economic condition of Greece, the main cause for emigration, affected the development of the armed forces. In spite of a large merchant fleet and thriving commercial colonies abroad, the Greek Kingdom's prosperity was marginal. Its industry remained in a fledgling stage, and most of its limited mineral resources were being developed by foreign concerns. Agriculture, besides that dealing with subsistence, was confined mostly to the export of currants. Greece, with little arable land, depended on food imports, commerce, foreign investment, and loans for its existence. Government revenues and expenditures were limited by the economy. Greece had difficulty sustaining a large standing army without indebting itself and adversely affecting its economy. The Greco-Turkish War of 1897 and its aftermath revealed these deficiencies in startling fashion.

Indeed, Greece's internal weaknesses and inability to achieve its external national goals made the "Megali Idea" a panacea for the problems of the Greek Kingdom. Some politicians, such as Kolletes and Deligiannes, saw the expansion of Greece as a solution to all its problems, internal and external; though others, like Mavrokordatos and Trikoupes, maintained that sound internal development, not irredentism, would assure Greece's prosperity and future expansion. These different views on state policy, especially the former, were used too often for personal or factional aggrandizement, rather than for the Greek national interest. ${ }^{11}$

\section{The Bandit-Guerrilla Tradition and the Greek Military}

The growth of the Greek army also suffered from a serious internal weakness. There was a striking contradiction between the military values of Greek society and the requirements of a military establishment based on the prevailing norms of European standing armies. At the time of the struggle for Greek independence and the emergence of the Modern Greek state, the Greeks, at the same time, relied on two opposing concepts: the bandit/guerrilla tradition of the native military elite and the conventional European notion of a regular army of the philhellenes and certain westernizing Greek leaders. The latter tendency had its foundation in the developed European practices of military organization strategy and tactics, while the former was a product of a military tradition that was prevalent throughout Greece and the Balkans. This tradition had it affinities with free mercenary companies of Europe prior to the eighteenth century.

The Greek tradition of arms, a warrior tradition as much as a military tradition, had its origins in the martial formations among Christians under

10. T. Saloutos, The Greeks in the United States (Cambridge, MA: Harvard University Press, 1964), 31.

11. R. Clogg, A Short History of Modern Greece (London: Cambridge University Press, 1979), 70-104. 
Ottoman rule. These formations included different types of fighters: klephtes, who resorted to brigandage as a means of livelihood and resistance to Ottoman authority; armatoloi and kapoi, who served Muslim and Christian authorities respectively as military retainers; the warrior communities of Mani and Souli; along with other elements that had their counterparts among other Balkan peoples. $^{12}$

The largest segment of the military leadership of the Greek Revolution stemmed from that tradition, which had undergone great expansion and change in the decades before the revolution as a result of the Russo-Turkish and Napoleonic wars. Many Greek chieftains had participated in large-scale uprisings against the Turks in the 1770s, 1790s, and 1800s (Pappas 1991: ch. 61-94). Also in this pre-revolutionary period the powers of Europe, especially Russia, had employed Greek warriors in units that served in the Crimea, the Danubian Principalities, Egypt, Ionian Islands, Italy, and Dalmatia. ${ }^{13}$

With the Greek War of Independence, the tradition achieved its apogee in Greece's tenacious and successful resistance to Ottoman authority under the leadership of such chieftains as Kolokotrones, Botsares, Karaiskakes, and Androutsos. And yet the contradiction of this tradition with western modes of warfare, which began to appear as Greeks served more and more in foreign armies, became pronounced during the revolution.

\section{Regular and Irregular Forces in the Greek Revolution - A Clash of Traditions}

A number of Greek insurgent leaders saw the need for regular forces after the experience of civil war within the Greek ranks, as well as by the urging of the philhellenes and representatives of the Great Powers. Although the performance of the regular forces of the Greeks during the revolution was undistinguished when compared to some of the guerrilla campaigns of Kolokotrones and Karaiskakes, their potential reliability to keep out of factional and regional strife, which plagued irregular forces, attracted some of the organizers of the insurgent Greek state. ${ }^{14}$

Although the organization of regular forces was advocated by a number of Greek leaders, most Greek men-of-arms were not attracted to service in them. The regular units of the Greek revolution were made up mostly of

12. N. Pappas, "Guerrilla Warfare in the Balkans, 1941-1945: A Historiographic Essay," in Papers of the U.S.M.A.- R.O.T.C. Military History Fellowship (West Point, NY: United States Military Academy, 1991), 21-59.

13. Ibid., 293-337, 353-357; N. Pappas, "Balkan Foreign Legions in Eighteenth-Century Italy: The Reggimento Real Macedone and its Successors," Nation and Ideology: Essays in Honor of Professor Wayne S. Vucinich, ed. I. Banac, J. G. Ackerman, R. Szporluk (New York: East European Monographs and Columbia University Press, 1983): 35-59

14. T. Veremis, "Kapodistrias and the French: The Formation of the Greek Regular Army," in East-Central European Society and War in the Era of Revolutions, 1775-1856, ed. Béla Király (New York, 1984), 256-270; C. Vyzantios, Historia ton kata ten Helleniken Epanastasin ekstrateion kai machon on symmeteschen ho taktikos stratos apo to 1821 mechri tou 1832 (Athens: K. Ralles, 1837), passim. 
philhellenes; Greeks from the Ionian Islands and elsewhere, who were used to western military service; and at the end of the revolution, foreign regular troops. ${ }^{15}$ The military ideal of the Greek peasants during the revolution and for long after was not the regular soldier or officer, but rather the klephtes or armatolos, who was famed in folk song and lore and was the repository of all the virtues of Greek manhood. He was proud, honorable, courageous, pious, brave, and crafty. He was an expert at klephtopolemos, klephtic or Albanian warfare, a form of guerrilla warfare which entailed swift movements, sharpshooting, and hand-to-hand fighting. ${ }^{16}$

This form of warfare was suited to the mostly mountainous terrain of Greece and was very different from western tactics at the time. It emphasized small unit actions, hit-and-run attacks, and individual initiative over large drilled actions, sustained battles and rigid discipline. In many ways klephtopolemos, later known as antartopolemos (insurgent warfare), bears greater resemblance to modern warfare (particularly of the unconventional kind) than does the military art of Europe after the Napoleonic wars. However, this form of warfare had little or no tradition of arms outside of light infantry.

The techniques of artillery, fortification, and siegecraft were limited and improvised from Ottoman or western practice learned before and during the revolution. For example, Peloponnesian warriors learned the use of light artillery while in Russian service on the Ionian Islands in the years 1804$1807^{17}$. Nevertheless, a lacuna remained in the tactics of the Greek military tradition which was a factor that limited the effectiveness of Greek irregular forces against a regular army, such as the European-trained Egyptian forces of Ibrahim Pasha.

Greek warriors, unlike western soldiers, did not emphasize drill or discipline. The military authority of Greek tradition was basically different from the European chain of command in form and content. The basic rank of authority was the kapitanios, who led a band of varying size. Below him was his retinue (known as an oura, or tail) of immediate retainers, known as palikaria (or braves), headed by his adjutant, known as a protopalikari (first palikari). Above the kapitanios in large operations, there could be an archegos or oplarchegos (a chieftain). The criterion for rank was not based on discipline, ability, and achievement of duty, as in European armies, but rather upon patronage, kinship, or personal reputation. Family reputation was especially important in areas where hereditary leadership was a tradition, as in the armatoliks of western Roumeli or in the clan communities Cheimarra, Mani and Souli. Personal reputation was acquired by feats of bravery and by a demeanor of leadership. This subjective form of command and discipline made the traditional leaders more susceptible to indulging in factional strife and party

15. Genikon Epiteleion Stratou. Dieuthynsis Historias Stratou Historia tes Organoseos tou Hellenikou Stratou 1821-1954, 1957, 3-4, 9-11.

16. A. Vakalopoulos, Ta Hellenika Strateumata tou 1821: organose, ege sia, taktike, ethe, psychologia (Thessalonike: Hellenike Iatrike, 1948), 131-156.

17. A. Goudas, "Letter of Emmanuel Papadopoulos to Anagnostaras," July 12, 1805, Bioi Paralleloi, vol. 4 (Athens N. P. Peridos, 1889), 257-259. 
politics to enhance their position in a nebulous military hierarchy. ${ }^{18}$

The irregulars were recruited and maintained by their commanders, much like mercenary companies of Europe before the eighteenth century. A kapetanios received pay for his unit in a lump sum and distributed the salaries, often alotting pay according to the perceived merit of each individual soldier. Irregulars supplied their own weapons and were not liable for inspection and review as regular troops. These problems, along with a lack of quarter mastering and pay, embroiled the irregular soldiery in civil strife and brigandage. Desertion and the "summer patriot" were also symptoms of these problems. $^{19}$

It could be said that irregular troops of the Greek Revolution came from a tradition that is hard to trace. Did this tradition stem from banditry (klephtouria) and resistance to Ottoman rule, or did it emerge from the military formations that served the Ottomans (armatoloi and kapoi)? The question is made even more complex when one takes into account that prior to the Greek revolution many Greeks served in provisional and regular formations sponsored by Venice (Reggimento Cimarriotto), Naples (Reggimento Real Macedone), Russia (Albanskoi Voisko, Balaklavskii Grecheskii Polk, Odesskoi Grecheskii Divizion, Legion Legkikh Strelkov), France (Le Legion Grecque, Battalion de Chasseurs d'Orient, Le Regiment Albanaise); Great Britain (The 1st and 2nd Greek Light Infantry Regiments); and the United States (Greek Company). ${ }^{20}$

Even though the origins of the irregulars cannot be clearly traced to either banditry or mercenary service, it can be said that both Greek irregular troops and bandits (klephtes) shared many of the mores and customs found among all rural Greeks, especially those involved in nomadic and semi-nomadic livestock breeding. The bandit way of life often heightened the significance of these values and practices. Blood and ritual kinship ties were strong among irregulars and klephtes; alliances generally resulted from marriage, godfatherhood (koumparia), or blood brotherhood (adelphopoiesis in Greek, vlami in Albanian). The irregulars and klephtes also maintained a strict code of behavior based upon a concept of personal honor (philotimo) and the inviolability of an oath (besa). Violations were subject to punishment, and systems of revenge and satisfaction often leading to blood feuds were the principle means of settling disputes. The irregulars or klephtes, however, were far from Robin Hoods or disciplined soldiers. They engaged in livestock rustling, robbery, kidnapping, extortion, whether on an independent basis, or when sanctioned by a state authority as part of the military or security forces. ${ }^{21}$

The basic economic root of banditry in Greece was theft of livestock. Rustling of sheep and goats was a virtual sport among Greeks, Vlachs and Albanians of the mountain regions. Among some communities a young man was not considered a worthy bridegroom until he had shown his bravery, guile,

18. A. Vakalopoulos, Ta Hellenika Strateumata tou 1821: organose, ege sia, taktike, ethe, psychologia, 1948, 178-185, 188-194.

19. Ibid., 186-194.

20. N. Pappas, Guerrilla Warfare in the Balkans, 1941-1945: A Historiographic Essay, 1991, passim.

21. P. Rodakes, Klephtes kai Armatoloi (Athens: Atermon, 1975), 233-235. 
and audacity by the rustling livestock. Often these activities led to violent confrontations between families, communities, and broader authorities. These confrontations would in make perpetrators "take to the branch," become outlaws from local or central authority. The basic social institution of the klephtes was the band, which coagulated from the necessity of survival and livelihood; its cement was the ties of blood and ritual kinship described above $^{22}$.

The assets and liabilities of the regular and irregular traditions and their products, the regular and irregular forces of Greece, were a matter of controversy to historians and the leadership of that time. But to the common soldiers, the Greek peasants of that era, the issue was clearer. The regimentation, the forms of training and fighting in an army based on western modes were alien and unappealing to them. The attire of a klephtes, an antartes (insurgent, guerrilla), or an irregular consisted of: a fez or fur cap as headgear; a yeleki or vest; a phoustanella or pleated kilt, or doulamas (a knee-long tunic); kaltses or longstockings; tsarouchia or cowhide mocassins; and the kapa or shepherd's cloak. It was based on Greek peasant attire and was recognized and respected. By contrast, among the Greeks of the nineteenth century, the regular troops in European style uniforms, especially with the stena or trousers, were derided as psalidokeria (candlesnuffers) or splenantera (stuffed spleens). ${ }^{23}$

In the years immediately following the revolution, the contradiction between the two tendencies or traditions became more intense and the feelings among Greeks with regard to irregular and regular forces became more polarized. Following the assassination of Kapodistrias in 1831 and up until the arrival of the chosen king of Greece, Otto or Othon of Bavaria, the country was plunged into civil war in which the irregular forces of the state, the Light Battalions, became thoroughly embroiled. These units were subsequently disbanded and reorganized in an attempt to remove them from the party politics that had grown in the strife. At the same time, the tactical forces remained for the most part aloof of the factional conflict, but became a shadow numerically as a result of the departure of French and philhellene troops. ${ }^{24}$

\section{The Reign of King Otto and the Exacerbation of the Problem}

The arrival of Prince Otto, his regency and a Bavarian Guard of 4,000 troops changed the situation to completely favor a western-style army. The Bavarian regency set into motion a program to eliminate the forces that had fought the revolution and replace them with a regular army whose bulk would be Bavarian or German mercenaries until native Greek cadres could replace them. This program was carried out: (1) by disbanding the remnants of the

22. J. Koliopoulos, Brigands with a Cause: Brigandage and Irredentism in Modern Greece 1821-1912 (Oxford: Oxford University Press, 1987), 21-27.

23. P. Rodakes, Klephtes kai Armatoloi (Athens: Atermon, 1975), 224; A. Vakalopoulos, Ta Hellenika Strateumata tou 1821: organose, ege sia, taktike, ethe, psychologia, 1948, 174

24. Genikon Epiteleion Stratou. Dieuthynsis Historias Stratou, Historia tes Organoseos tou Hellenikou Stratou 1821-1954, 1957, 25. 
regular forces and reorganizing them with the Bavarians as a core, consisting of nearly 8,000 men; (2) by disbanding irregular forces and replacing them with new semi-regular forces, known as Akrovolistai, skirmishers, consisting of about 2,000 men; and (3) by abolishing the bearing of arms. ${ }^{25}$

The majority of veterans of the revolution did not join the army, neither the regular nor skirmisher battalions, and were obliged to return home; some entered into Turkish service across the border, while others resorted to the old and honored profession of banditry. This reversion was not considered a criminal act among the general population, but a return to the Klephtic tradition. $^{26}$

In the eyes of many, Greece became virtually an occupied country under an army made up mostly of Bavarians. Units consisted of battalions that were mixed units down to the company level; half-Bavarian, half-Greek. The key staff positions were held by Bavarians or philhellenes in the early years of the kingdom. The Royal Greek army at its inception was not only Europeanized, but virtually a colonial institution.

As a result of these policies, resentment toward this situation and others manifested itself in the unrest of the ensuing years of the era King Otto (18331866). Twenty-eight coups, insurrections and disturbances occurred during Otto's reign in which military elements took an active part. ${ }^{27}$ Many of these disturbances took the form of bandit activity led by veterans of the revolution. There were cases in which banditry became so rampant that whole areas seemed to be in full-scale revolt. Regular army troops deployed to suppress these disturbances met with resistance and difficulty. In most cases the authorities were only able to quell banditry by playing one chieftain or group against another, or by granting concessions and amnesties. A case in point was the Maniate Revolt of 1834. In this uprising in one of the clan regions of Greece a 2,500-man Bavarian force was mauled by the rebels and the government was forced to grant autonomous measures and even agreed to a Maniate military force. ${ }^{28}$ In another instance in 1835 , regular troops were sent on expedition against former irregulars in the mountains of Roumeli. These regular troops were unused to the klephtic style of fighting and unequal to the mountain campaigning. Irregular bands had to be co-opted and employed as a national guard in combating brigandage. ${ }^{29}$ In the constitutional revolution of 1843, tactical Greek officers, such as Kallerges, cooperated with traditional military leaders and other irregular elements. This movement brought the first

25. Ibid., 26-27.

26. K. Mendelssohn-Bartholdy, Geschichte Griechenlands von der Eberung Konstantinopels durch die Türken in Jahre 1453 bis auf unsere Tage. v. 2, 1874, 450-451.

27. Genikon Epiteleion Stratou. Dieuthynsis Historias Stratou, Historia tes Organoseos tou Hellenikou Stratou 1821-1954, 1957, 43.

28. Ibid., 30; K. Mendelssohn-Bartholdy, Geschichte Griechenlands von der Eberung Konstantinopels durch die Türken in Jahre 1453 bis auf unsere Tage. v. 2, 1874, 491.

29. J. Koliopoulos, Brigands with a Cause: Brigandage and Irredentism in Modern Greece 1821-1912, 1987, 85-86; J. Koliopoulos, "Captains, Brigands, and Irregulars of Central Greece in Times of Crisis and Revolution, 1833-1854," in East-Central European Society and War in the Era of Revolutions, 1775-1856. ed. B. Király (New York: Brooklyn College Press and Columbia University Press, 1984), 305-306. 
limitations upon the monarchy and removed foreigners from government positions with the exception of philhellene veterans.

However, the Bavarian and foreign troops began leaving much earlier in 1837 when their enlistments began expiring, despite efforts to induce reenlistment. This exodus of foreign troops was a mixed blessing, in that it led to a manpower shortage in the Greek army. In the first three decades of development (1833-1863), the standing army of the Greek state actually declined in strength. ${ }^{30}$ Throughout those years, there was a constant flux in the formation of units, particularly in the infantry. This, it seems, was partly due to efforts in trying to reconcile the regular units with the Greeks' inclination toward irregular units. In the thirty years of the reign of King Othon, the number, composition, and nomenclature of infantry battalions was changed no less than ten times. ${ }^{31}$

This period saw a number of attempts to form units that would attract Greeks to military service. The formation of the Chorophylake in 1833 was the first such attempt to incorporate veteran irregulars into a state formation. This force, equated with the French gendarmes, became in time the national police force in Greece. However, in its initial form it resembled the armatoloi of the Ottoman Empire. While the uniforms of the Chorophylake were western, the duties, command structure, tactics, pay, and personnel were similar to those of the irregular troops. ${ }^{32}$ There were also the above-mentioned Akrovolistai or skirmishers, who were allowed traditional dress and some tactics, but who were placed under regular army discipline. Later accommodations included the Evzones, light infantry in traditional garb that were integrated into regular army battalions, until 1867 when they were formed into their own battalions. ${ }^{33}$

Besides these types of troops in the standing army there were also the Orophylakoi or border guards, the Metavatikoi or mobile troops and the Ethnophylakoi or National Guard, organized into units that were outside of the scope of the regular army. The organization and pay of these units was not fully regulated and this made for abuses within these units. Leaders and troops would use their positions to extort favors and pay from local inhabitants. In many instances, the distinction between some of these troops and bandits was blurred. There was also an honorary force, known as the Phalanx, which was composed of those veteran leaders and chieftains of the revolution who were not placed in the regular army. These men were brought before a committee, which gave each veteran one of five honorary ranks. They were consigned to honorary units which offered pensions and were called up for state ceremonies. ${ }^{34}$ These compromises and others to the native Greek tradition of arms were not enough

30. Genikon Epiteleion Stratou. Dieuthynsis Historias Stratou, Historia tes Organoseos tou Hellenikou Stratou 1821-1954, 1957, 31.

31. Ibid.

32. Koliopoulos, Brigands with a Cause: Brigandage and Irredentism in Modern Greece 1821-1912, 1987, 78-79

33. Genikon Epiteleion Stratou. Dieuthynsis Historias Stratou, Historia tes Organoseos tou Hellenikou Stratou 1821-1954, 1957, 31; N. Kteniades, He Hellenike Chorophylake: Historikai selides, ed. 2. Athens, 1960.

34. Genikon Epiteleion Stratou. Dieuthynsis Historias Stratou, Historia tes Organoseos tou Hellenikou Stratou 1821-1954, 1957, 31. 
to alleviate weaknesses that had arisen from the misbegotten effort to establish a western-style army, which required the hiring of foreign mercenaries, and the disbanding of native troops trained in mountain warfare. The later problems of a weak army, banditry, and politicization of the military were the legacy of these policies.

\section{Irregulars and Bandits in $19^{\text {th }}$ Century Greece}

In many instances, the distinction between some of these irregular troops and bandits was blurred. There were many cases in which irregulars took to banditry or service across the border in Turkish armatoloi forces. There were other cases in which bandits were amnestied and co-opted into service in one of the abovementioned Greek formations. In most cases these units were formed and operated for two purposes. In times of peace they were organized to suppress banditry and often engaged it in it themselves. In times of war they were used to form irregular forces to challenge Turkish authority in unredeemed Greek lands. ${ }^{35}$

When a regular recruiting and draft system was organized in Greece in 1838 , it displayed the same problems as did the organization of the army. The system was very similar to the selective service used in the U.S. between 1948 and 1968. Recruitment depended on volunteers and draftees. Volunteers enlisted at the local nomarchia (county or department) while those drafted were chosen from the census catalogs. Those selected served in the army for four years (three years after 1857), but had the right to furnish a replacement. Those exempted included married men, university and gymnasium students, clergy, teachers, doctors, and only sons.

In each community, after volunteers were subtracted, draftees were chosen by lot and examined by a provincial recruiting council. Inductees were then sent to one of seven area mustering points, where their placement into different forces was made. ${ }^{36}$ This was a very inefficient and corrupt system of recruitment. Men who were not on good terms with the local authorities were commonly selected for service. Many of the men of higher martial potential were attracted to irregular state forces or to brigandage. ${ }^{37}$

The men who took to banditry were not criminals. Many, as has been mentioned, were veterans of the revolution, who had taken "to the branch," as the Greeks say, to alleviate the post-war destitution. Others entered into the outlaw life to avoid prosecution from a crime of honor, or from a vindictive government official. They were, as they had been in Ottoman times, opponents to a centralized state. Local populations often looked upon them with fear and respect. Some groups in the countryside, notably mountain villagers and

35. Koliopoulos, Brigands with a Cause: Brigandage and Irredentism in Modern Greece 1821-1912, 1987, passim.

36. Genikon Epiteleion Stratou. Dieuthynsis Historias Stratou, Historia tes Organoseos tou Hellenikou Stratou 1821-1954, 1957, 31.

37. J. Campbell, "Greek Society and Politics under King Otho, 1843-1862," in St. Anthony's East European Seminar (Oxford St. Anthony's College, 1960), 10 
livestock breeders, abetted them in their activities. Some of these klephtes of nineteenth-century Greece achieved wide fame as a result of their exploits for the government as irregulars and against the government as bandits. ${ }^{38}$

In his studies on banditry in $19^{\text {th }}$ century Greece, John Koliopoulos prefers to refer to the bandits as lestes, which was a term used in official circles and the government in order to separate the outlaws against the Greek state from those outlaws of the Ottoman empire which played such an important role in the struggle for Greek independence. This author prefers the term klephtes, because this was the term use by the bandits themselves and the country people who came into contact with them as collaborators or as victims. Folksongs of rural Greece, as well as oral traditions referring to bandits use the term klephtes, not lestes. Their important position in Greek affairs cannot alone be explained by their monopoly of force in the countryside. It also has to be explained by their being a traditional symbol of resistance to central authority whether from Constantinople or Athens. ${ }^{39}$

\section{Bandits, Irregulars and Irredentism}

The klephtes and irregulars would often align themselves and their bands with political leaders and parties. For instance, Ioannes Kolletes and his followers maintained a number of chieftains and bands in their pay. Because of the influence and power wielded by the klephtes in a number of localities, they were useful in providing popular and armed support in an era when parliamentary and electoral democracy was in a rudimentary stage. ${ }^{40}$ Also Kolletes and other irredentist politicians believed that a foreign policy of expansion could be manufactured, if not realized; by using armed bands of pardoned klephtes and other volunteers, in conjunction with Greek nationalist groups in unredeemed areas, to defend Greek claims, to foment uprisings and to eventually bring about annexation to Greece. These irregular forces sponsored semi-officially or unofficially, were known in official circles as antartes, which in Greek means guerrillas or insurgents. ${ }^{41}$

During the Crimean War, bands of antartes were active in revolts in Epirus, Macedonia, and Thessaly, many of them led by veterans of the Greek Revolution. ${ }^{42}$ Also in that war, a Greek legion was organized in the Danubian Principalities which fought in the Russian army in Crimea at the siege of

38. Koliopoulos, Brigands with a Cause: Brigandage and Irredentism in Modern Greece 1821-1912, 1987, 278-292.

39. Koliopoulos, Captains, Brigands, and Irregulars of Central Greece in Times of Crisis and Revolution, 1833-1854, 1984, 303. In his Greek works Koliopoulos uses the term lestes, while in his later book, Koliopoulos 1987 he does not use the term, instead he uses the English term "brigand".

40. Ibid., 1987,121-134

41. Koliopoulos, Brigands with a Cause: Brigandage and Irredentism in Modern Greece 1821-1912, 1987, 320-321, Koliopoulos, Captains, Brigands, and Irregulars of Central Greece in Times of Crisis and Revolution, 1833-1854, 1984, 314.

42. On Greece in the Crimean War, see Dontas 1973; Kofas, 1980; Nomikos, 1967; Karatzenes, 1973; Koutroumpas, 1976; Malamakes, 1967; Papadopoulos, 1970; Papageorgiou, 1959; Papageorgiou 1960; Vakalopoulos, 1956; Todorova, 1984; and Vasdravelles, 1961-1963. 
Sevastopol. $^{43}$

In the Cretan Revolution of 1866-1868, antartes units as well as army cadres were raised and sent from the kingdom to link up with the Cretan insurgents. These bands included many klephtes given promises of amnesty. When the outcome of that crisis was adverse, and the government was unable to fulfill its promises or control these antartes/klephtes, banditry in Greece spread. ${ }^{44}$ It became an international problem when a group of Western Europeans was murdered by brigands in 1869. Pressure was brought upon Greece by the Great Powers to set its house in order. ${ }^{45}$ Efforts by Greek governments to suppress banditry met with mixed success, however, since some leaders had use for the klephtes/antartes and policy toward them vacillated. For example, in 1871, harsh legislation was passed which called for the arrest and incarceration of anyone suspected of aiding bandits. Army and Gendarme units were called upon to shoot bandits on the spot, to save the state money in trying and incarcerating them. These measures did not stop the syndrome of bandits, but rather led many to seek asylum in adjacent Ottoman provinces. ${ }^{46}$

In the latter third of the nineteenth century, irregular forces of bandit origins were often sponsored by national and irredentist groups, such as Ethnike Amyne (National Defense), and Ethnike Hetaireia (National Society). The former was active in the organization of bands for Epirus, Macedonia and Thessaly during the Eastern Crisis of 1875-1878 and its aftermath (18771878). ${ }^{47}$ The latter was involved in supplying irregulars and arms during the Cretan uprising of 1896-97 and prepared antartes bands especially for the northern areas of Epirus and Macedonia. The Ethnike Hetaireia, a powerful organization which had sympathizers and members in the army, the church and the government, is said to have been one of the forces behind Greece's untimely war with Turkey in $1897 .^{48}$

A problem that arose in virtually all these conflicts involving Greece in the 19th century was the recruitment and conduct of irregular bands in these conflicts. As shown by John Koliopoulos in his studies of Greek banditry, the granting of amnesty to bandits, their activities during and after these

43. A. Chrysoverges, Historia tes Hellenikes Legeonos. Oligai lexeis peri tou Somatos ton Hellenon kai meta tauta Hellenike Legeon Autokratoros Nikolaou to Protou. Historike Diegesis. 2 vols. (Odessa: Odeskago Vestnika, 1887-1888); T. Gkalioures, Apomnemoneumata tes Hellenikes Phallangos tou Autokratoros pason ton Rossion Nikolaou to A' (Athens: Niketas Passares, 1865); and K. Ramphos, Ta ten Helleniken Legeona tou Autokratoros Nikolaou A' ten kata to 1853 en Moldovlachia systetheisan aphoronta (Athens: Demetrios Syllivriotes, 1867).

44. Koliopoulos, Brigands with a Cause: Brigandage and Irredentism in Modern Greece 1821-1912, 1987, 181-189.

45. T. Vournas, To Goudi. To Kinema tou 1909 (Athens: Techne-Episteme, 1957).

46. Koliopoulos, Brigands with a Cause: Brigandage and Irredentism in Modern Greece 1821-1912, 1987, 189-192.

47. On Greek irregular bands in 1878, see Koliopoulos, 1987: 193-204; Kofos, 1969; Seizanes, 1878; Pappas, 2006.

48. Koliopoulos, Brigands with a Cause: Brigandage and Irredentism in Modern Greece 1821-1912, 1987, 213-222; G. Lyritsis, He Ethnike Hetaireia kai he drasis tes (Kozani, 1979); A. Mazarakes-Ainian, Historike Melete 1821-1897 kai ho Polemos tou 1897 (Athens:

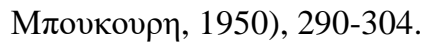


wars and crises, led to a serious instability in the Greek countryside. The distinction between conflict and criminal activity, military service and banditry, in these periods was not clear. As Koliopoulos puts it ${ }^{49}$

Unable to monopolize violence, the Greek state tried to control illegitimate group violence by providing two acceptable channels, irredentist activity and incorporation of bandits into paramilitary units; which created a semblance of legitimacy in the exercise of non-state authority and at the same time rendered such pursuits less dangerous to the security of the state.

In his studies, Koliopoulos also makes it clear that "the military traditions associated with them [the bandits] appear to have been one of the most enduring obstacles to the growth of the regular army equal to the internal requirements and the national aspirations of the country." While Koliopoulos describes the affect of bandits and irregulars upon the uneven development of the Greek army, he does not go into how and why the influence of brigands was eventually mitigated. ${ }^{50}$

The Greco-Turkish war of 1897 seems to have been a watershed for the development of the regular Greek army and decline of the irregulars and banditry. Since the change of dynasty in 1863, although some improvements were made, the development of the Greek army was haphazard. The Greek government changed its military policy with the proclivities of whoever was in power. The governments of Charilaos Trikoupes, for example, took special concern for the firm growth of the armed forces, but were not in favor of flamboyant military expenditures or adventures. Conversely, though, other governments such as those of Deligiannes, were aggressive in foreign policy, but did not spend as much for the army. They spent more funding irredentist organizations and irregular bands. Furthermore, the economic condition of the country, especially in the 1890 s, constricted the growth of the armed forces. The weaknesses of the Greek army were demonstrated in an incompetent, clumsy occupation of Thessaly in the wake of the Russo-Turkish War in 1881 and the sluggish mobilization in response to Bulgarian annexation of Eastern Rumelia in 1885. Yet, aside from Trikoupes' efforts, no great improvements were made up to the 1897 war. ${ }^{51}$ The shock of defeat in 1897 along with the realization that Bulgaria was a rival in Macedonian guerrilla struggle of the years 1900-1908, awakened many political leaders and officers to the need of a strong standing army. ${ }^{52}$

In the complicated and multi-faceted contest in Macedonia, where the Balkan states, along with the Ottoman administration, were vying for the allegiance and control of its mixed population, young Greek officers like Pavlos Melas, the Mazarakes brothers and Georgios Tsondos, participated in supporting Greek interest. A number of Greek officers, often absent without leave, led bands of Cretan, Greek, and local antartes in Macedonia in the first

49. Koliopoulos, Brigands with a Cause: Brigandage and Irredentism in Modern Greece 1821-1912, 1987, 293

50. Ibid., 19.

51. Mazarakes-Ainian, Historike Melete 1821-1897 kai ho Polemos tou 1897, 308-313

52. Ibid., 322-323. 
decade of the twentieth century. ${ }^{53}$ Their experiences gave further realistic evidence of the tenuousness of the Greek position in the Balkans vis-a-vis the other Balkan states, especially Bulgaria. ${ }^{54}$ The Young Turk Revolution of 1908, and the nationalist reform movement that followed, offered the Greeks the prospect of confronting not only the rivalry to its irredentism of the other Christian states, but also of a resuscitated Ottoman regime.

\section{The Growth of Modern Armed Forces in Greece}

Greece, in spite of the financial strictures put upon it by the Powers, had been making progress in the development of the military from the year 1904 . Measures were attempted to reorganize the army into large divisional units on a permanent basis, to establish an efficient general staff, to improve the training of officers and men, to form a national defense fund, and to regularize universal conscription and mobilization. Universal conscription, though instituted in Greece as early as 1878, had never been fully implemented; likewise, mobilization procedures of the armed forces had not been put on a good footing. Refitting the army with new weapons was also begun, but the strength of forces was reduced in order to fund the new arms purchases 55 .

Although the armed forces of Greece were showing improvement in the period 1904-1909, the full realization of their potential was hindered by the oligarchic dynamics of the Greek governments and politics. Parliamentary crises and changes of regime were frequent and the need for a change in the situation became evident, especially when pressures of the Young Turks in 1908-1909 over Crete once again had humiliated Greece internationally. The question of union with Crete came up again and Greece by its own weaknesses was forced to back down. Indeed, in that crisis, the French Premier Clemenceau denigrated Greek aspirations by stating: "Your claims are not favorably accepted, since you are not strong. You are the weakest of all the Balkan states." 56

The political establishment with its old practices of patronage and personal aggrandizement was incapable of forming a Greece that could make good its claims. As one historian of the period has colorfully commented: ${ }^{57}$

The frequent changes of governments does not always indicate decline, on the contrary it can be an indication of political vigilance and vitality. But in the Greece of the 1900s, the changes of governments manifested simply the perplexity and panic of men before an unburied corpse. That corpse was called political feudalism. Common people named it old party-ism. Until one day some brave men threw it into a grave and half-buried it with earth. Later they fastened a

53. D. Dakin, The Greek Struggle in Macedonia (Thessalonike: Institute for Balkan Studies, 1966), 319.

54. Mazarakes-Ainian, Historike Melete 1821-1897 kai ho Polemos tou 1897, 325-326.

55. Genikon Epiteleion Stratou. Dieuthynsis Historias Stratou, Historia tes Organoseos tou Hellenikou Stratou 1821-1954, 1957, 100-101

56. G. Venteres (). He Hellas tou 1910-1920. vol. 1 (Athen: Pyrsos,1931), 38.

57. P. Enepekides, He Doxa hai ho Dichasmos (Athens: Bires, 1962), 12. 
plaque on a sword, placed the sword in the tomb's earth and wrote on the plaque: "Goudi-August 1909. MILITARY LEAGUE."

The revolution of 1909 was decisive in the evolution of the Greek army. ${ }^{58}$ The short-lived officers' government and the subsequent Venizelos administration, aside from laying the groundwork for the first political and social reform in Greece in decades, brought about a phenomenal development of the Greek army. Soon after their coup the Military League issued a "Program for the Military Organization of the Land and Sea Forces," which presented farreaching reforms for the armed forces. ${ }^{59}$ In the ensuing three years under them and Venizelos, many of these measures were realized. Among the achievements accomplished in this short time were: (1) the abolition of deferments and irregularities in the draft and the realization of universal conscription; 2) the recall and training of all men--inductees, veterans, deferrers and the untrained-of the military classes from 1899 onward; (3) the retraining of captains in special schools; (4) the training of staff officers for commanding large units; (5) the organization of the army into divisional units for both peacetime and wartime; (6) the full provisioning of arms and material; and (7) the calling of the Eydoux French Military Mission, the first such in thirty years, for the overseeing of the reorganization and training of the army (102).

Moreover, the generous help of wealthy Greeks abroad, known as benefactors of the Nation (ethnikoi evergetes), aided in the reforms. While they were known for the financing and building of charitable institutions and schools, they now donated for the Greek armed forces. One benefactor, Georgios Averof, sponsored new facilities for the Military Academy (Schole Evelpidon) of the Greek Army and gave funds for the construction of what became the flagship of the Greek Navy, the battlecruiser Averof. ${ }^{60}$ Aside from these wealthy overseas Greeks, in 1912-1913, over 30,000 Greek emigrants in America returned to the homeland to serve in the Greek Army and Navy ${ }^{61}$.

The results were remarkable. Before the 1909 coup, members of the General Staff, having the leaders and legacy of 1897 to narrow their vision, could not foresee a Greek army equal to its neighbors. For example, the then First Lieutenant and future dictator, Ioannes Metaxas, in a report entitled "Concerning a Turco-Bulgarian Conflict, if that were to occur," stated that it was impossible for Greece to field an army any larger than 60,000 men, and

58. See V. Papacosma, The Military in Greek Politics: The 1909 Coup d'Etat (Kent, OH: Kent State University Press, 1977), passim.

59. For a text of this program, see: M. Malainos, He Epanastasis tou 1909 (Athens: Athena, 1965), 86-90. Other works concerning the Military League and 1909 include: Epanastasis 1909. To Archeion Stratiotikou Syndesmou 1972; I. Pangalos, Ta Apomnemoneumata mou, 1897-1947 (Athens: Kedros, 1959); and T. Vournas, To Goudi. To Kinema tou 1909 (Athens: Techne-Episteme, 1957).

60. S. Kamalakes, He evergetike prosphora tou Aigyptiote Hellenismou. Aigyptiotes ethnikoi ethnikoi evergetes, ed. 2 (Athens: Angelakes, 2012), 30.

61. D. Cassavetes, Hellas and the Balkan Wars (London: Unwin, 1914), 21-22; N. Pappas, "Misinterpretations and Miscalculations of Contemporary Reports on the Balkan Wars," in The Centenary of the Balkan Wars (1912-1913): Contested Stances, vol. 1 (Ankara, Turkey: Turkish Historical Society, 2015), 50. 
that after some years ${ }^{62}$. Yet three years later, at the outbreak of the Balkan Wars, Greece fielded an army of about 115,000 men that was larger, better organized and better trained than the army of $1897^{63}$.

This new army, in the midst of its successful campaigns against the Ottomans in Macedonia and Epirus, continued its organization and expansion in view of the falling out and was with Bulgaria. By the end of 1913 the army had a strength of 200,000 men and was organized into five army corps with combat and support units ${ }^{64}$. Its training and equipment were comparable to that of its neighbors' armies. In certain arms, such as artillery, the Greek army was ahead of those of other Balkan states.

The contradiction between the traditional and western in Greek military affairs had subsided over the years. The Greek army had slowly integrated within its ranks evzone units, first battalions, later regiments, that kept traditional garb and customs while adopting military discipline. These evolved into the crack light infantry units of the Greek army, and they, along with the more recently mustered Cretan regiments, and became Greece's equivalent of the Scots highland regiments of the British army. By 1914, Greece had five evzone and three Cretan regiments ${ }^{65}$. In addition to this, some antartes continued to play a role in military activities, but came more under the control of the army and government.

\section{The Two World Wars and New Challenges}

At the threshold of the First World War, the Greek army had reached a new apogee in strength and ability. It was larger, better trained, and better equipped than it had been at any other time since its inception. It was a victor of two successive wars in conjunction with its Balkan allies and had become the bulwark for a vigorous foreign policy as advocated by Venizelos. It seems as if Greek leaders had finally learned that an irredentist policy had to be backed up by a strong standing army, besides diplomacy, irregulars, and propaganda.

The old links and tension between the bandit and soldier in Greece supposedly ended with the growth of the regular Greek army in the years 19121914. This army became divided over the question of Greece's entry into the First World War. It met with military disaster in the Greco-Turkish War of 1919-1922 and became further factionalized in the struggle between politicians and officers who supported either monarchy or republic. The army became a factor in politics in the interwar period with officers participating in Military dictatorships, such as those of Pangalos, Kondylis and Metaxas (105-135). The

62. Malainos, He Epanastasis tou 1909, 1965, 55-56; and Epanastasis 1909. To Archeion Stratiotikou Syndesmou, 1972: 9.

63. Pappas, Misinterpretations and Miscalculations of Contemporary Reports on the Balkan Wars, 2015, 47-48.

64. Genikon Epiteleion Stratou. Dieuthynsis Historias Stratou, Historia tes Organoseos tou Hellenikou Stratou 1821-1954, 1957, 106-108; Pappas, Misinterpretations and Miscalculations of Contemporary Reports on the Balkan Wars, 2015: 47-48

65. Genikon Epiteleion Stratou. Dieuthynsis Historias Stratou, Historia tes Organoseos tou Hellenikou Stratou 1821-1954, 1957, 106-108. 
Greek army was dissolved during the Axis occupation, and the Greek countryside again saw the rise of irregular forces, but in this case guerrillas and partisans (antartes) sponsored by political coalitions and parties, most notably the National Liberation Front (E.A.M.) and the Greek Communist Party(On Greece under the Occupation) ${ }^{66}$.

During the occupation and civil war that followed, both the Left and the right made use of allusions to the klephtic tradition in their propaganda. The Communists called their wartime resistance movement and post-war insurgency "the new 1821" and their partisan fighters, "the klephtes and armatoloi reborn." The Royalist government called their opponents, brigands (lestes) and officially called the Greek Civil War of 1946-1949 the Symmoritopolemos, "the war against the [brigand] gangs." In a strange way opposing forces in the Greek Civil War used the terminology of both the official and unofficial Greece of the nineteenth century.

Some claim that these positive and negative harkenings to the past irregular forces are inaccurate and misleading. It states armed struggle in the Greek countryside in the decade of the 1940's was not a through back to either primitive rebels or bandits, but was rather part of the guerrilla warfare developed by twentieth-century political movements and states. It also asserts that the Greek antartes of the 1940's had more affinity to insurgent forces in Yugoslavia, China, Viet Nam, and elsewhere, than to the klephtes of the nineteenth century. However, unlike their counterparts in national liberation movements elsewhere in the Balkans and beyond, the antartes of ELAS did fly flags or where emblems with red stars. Instead, they flew the Greek national flag and wore national emblems on their uniforms. Moreover, the tripartite command structure of ELAS units was different from partisan forces in other countries in that they not only have a shared command of a regular or reserve army officer and a party cadre who acted as a political commissar, but also included a "popular commander," known as a kapetanios, from the irregular tradition. This style transcends ideology in that rival resistance organizations, such as EDES and EKKA also used national symbols. Even the Cypriot underground organization of the 1950, EOKA, led by the well-known anticommunist, Georgios Grivas, used the same tactics and symbols in their guerrilla war against the British. ${ }^{67}$

The growth of the Greek army and the decline of banditry came about at a time when the Powers of Europe were in a state of rivalry and realignment. Greece, like its neighbors, needed the loans, the armaments, and the advisors of one power or another to build up its army. The period before the First World War was an opportune one for small nations like Greece to expand their armed forces, with the burgeoning of rivalry of the Powers and the availability of arms. The ability for a country like Greece to maintain an army that it had in 1914 depended not only on the ability of its leadership and will of its people,

66. see Greece in the 1940's: A Nation in Crisis (1981) ed. J. O. Iatrides, (Hanover, NH: New England University Press) and Greece in the 1940's: A Bibliogaphic Companion, ed. J. O. Iatrides (Hanover, NH: New England University Press, 1981).

67. N. Pappas, Greeks in Russian Military Service in the Late Eighteenth and Early Nineteenth Century (Thessalonike: Institute for Balkan Studies, 1991). 
but also on the policies and actions of the Great Powers. The subsequent decades for Greece, with the national discord and external pressure over entry into the Great War, with the participation in the war and in the Allied intervention in Russia, and with the tragic adventure in Asia Minor, displayed that its military strength, though it had grown prodigiously, was limited by external elements that Greece could not control. The ensuing decades with their military dictatorships, occupation and civil war showed that a regular army could be as difficult to control by constituted governments as had been forces and bandits in the nineteenth century. Nevertheless, since the fall of the Military Junta and the return of civilian government in 1974 control of the regular armed forces have been strengthened, especially with the integration of Greece into the European Union, and the easing in tensions in the Balkans. What lies in the future, particularly with the turmoil in the Middle East and rise of an Islamist Turkey of Ertoğan, is unknown.

\section{Bibliography}

Campbell, J. "Greek Society and Politics under King Otho, 1843-1862." In St. Anthony's East European Seminar. Oxford: St. Anthony's College, 1960.

Cassavetes, D. Hellas and the Balkan Wars. London: Unwin, 1914.

Chrysoverges, A. Historia tes Hellenikes Legeonos. Oligai lexeis peri tou Somatos ton Hellenon kai meta tauta Hellenike Legeon Autokratoros Nikolaou to Protou. Historike Diegesis. 2 vols. Odessa: Odeskago Vestnika, 1887-1888.

Clogg, R. A Short History of Modern Greece. London: Cambridge University Press, 1979.

Corvisier, A. Armies and Societies in Europe, 1494-1789. Translated by A. T. Siddall, Bloomington, IN: Indiana University Press, 1979.

Dakin, D. The Greek Struggle in Macedonia. Thessalonike: Institute for Balkan Studies, 1966.

Dontas, D. He Hellas kai hai dynameis kata ton Krimaikon Polemon. Thessalonike: Institute for Balkan Studies, 1973.

Enepekides, P. (1962). He Doxa hai ho Dichasmos. Athens: Bires.

Epanastasis 1909. To Archeion Stratiotikou Syndesmou. Athens: Kedros, 1972.

Genikon Epiteleion Stratou. Dieuthynsis Historias Stratou. Historia tes Organoseos tou Hellenikou Stratou 1821-1954. Athens: Dieuthynsis Historias Stratou, 1957.

Gkalioures, T. Apomnemoneumata tes Hellenikes Phallangos tou Autokratoros pason ton Rossion Nikolaou to A'. Athens: Niketas Passares, 1865.

Goudas, A. "Letter of Emmanuel Papadopoulos to Anagnostaras." July 12, 1805. Bioi Paralleloi, vol. 4, 257-259. Athens: N. P. Peridos, 1889.

Greece in the 1940's: A Nation in Crisis. Edited by .J. O. Iatrides. Hanover, NH: New England University Press, 1981.

Greece in the 1940's: A Bibliogaphic Companion. Edited by J. O. Iatrides. Hanover, NH: New England University Press, 1981.

Grimmelshausen, H. J. C. The Adventures of a Simpleton, Translated by W. Wallich. New York: Ungar, 1963.

Inalcik, H. "The Socio-Political Effects of the Diffusion of Firearms in the Middle East." In War, Technology and Society in the Middle East, edited by V. J. Parry and M. E. Yapp. London. Oxford University, 1975.

Kamalakes, S. He evergetike prosphora tou Aigyptiote Hellenismou. Aigyptiotes 
ethnikoi ethnikoi evergetes. ed. 2. Athens: Angelakes, 2012.

Karatzenes, D. He epanastasis tes Artes tou 1854. Athens, 1973.

Kofas, J. International and Domestic Politics in Greece during the Crimean War. New York: East European Monographs and Columbia University, 1980.

Kofos, E. (ed.) He epanastasis tes Makedonias kata to 1878. Thessalonike: Institute for Balkan Studies, 1969.

Koliopoulos, J. "Lestes kai antartes sten kentrike Hellada to 1835-1836." Mnemon 7(1975): 118-134

Koliopoulos, J. Lestes: He kentrike Hellada sta mesa tou dekatou enatou aiona. Athens: Hermes, 1979.

Koliopoulos, J. Peri Koinonikon kai allon leston ste Neoteri Hellada. Deltion tes Historikes kai Ethnologikes Hetaireias tes Hellados 23(1980): 422-436

Koliopoulos, J. "Captains, Brigands, and Irregulars of Central Greece in Times of Crisis and Revolution, 1833-1854." In East-Central European Society and War in the Era of Revolutions, 1775-1856, edited by B. Király. New York: Brooklyn College Press and Columbia University Press, 1984.

Koliopoulos, J. Brigands with a Cause: Brigandage and Irredentism in Modern Greece 1821-1912. Oxford: Oxford University Press, 1987.

Koutroumpas, D. He epanastasis tou 1854 kai hai en Thessalia idia epicheiresis. Athens: University of Athens, 1976.

Kteniades, N. He Hellenike Chorophylake: Historikai selides, ed. 2. Athens, 1960.

Lyritsis, G. He Ethnike Hetaireia kai he drasis tes. Kozani, 1979.

Malainos, M. He Epanastasis tou 1909. Athens: Athena, 1965.

Malamakes, I. He ekstrateia tou Demetriou Tsame Karatasou ste Chalkydike to 1854. Thessalonike, 1967.

Markezines, S. Politike Historia tes Neoteras Hellados. v. 1. Athens: Papyros, 1966.

Mazarakes-Ainian, A. Historike Melete 1821-1897 kai ho Polemos tou 1897. Athens: Млочкоирџ, 1950

McNeill, W. H. The Pursuit of Power: Technology, Armed Force and Society Since A.D. 1000. Chicago: University of Chicago Press, 1982.

Mendelssohn-Bartholdy, K. Geschichte Griechenlands von der Eberung Konstantinopels durch die Türken in Jahre 1453 bis auf unsere Tage. v. 2. Leipzig: Verlag von G. Hirzel, 1874.

Nomikos, E. Greece and the Crimean War. Doctoral Dissertation, Stanford University, 1967.

Pangalos, I. Ta Apomnemoneumata mou, 1897-1947. Athens: Kedros, 1959.

Papacosma, V. The Military in Greek Politics: The 1909 Coup d'Etat. Kent, OH: Kent State University Press, 1977.

Papadopoulos, S. Hoi Epanastaseis tou 1854 kai 1878 sten Makedonia. Thessalonike: Hetairea Makedonikon Spoudon, 1970.

Papageorgiou, K. "He Epeirotike epanastasis tou 1854." Epeirotike Hestia 8(1959): 441-447, 543-548, 640-646, 775-782, 861-866, 955-961 and 9 (1960): 16-21, 117-122, 192-196, 277-283, 374-381, 470-473;

Papageorgiou, K. "He Epeirotike epanastasis tou 1854." Epeirotike Hestia 9(1960): 16-21, 117-122, 192-196, 277-283, 374-381, 470-473;

Pappas, N. "Balkan Foreign Legions in Eighteenth-Century Italy: The Reggimento Real Macedone and its Successors." Nation and Ideology: Essays in Honor of Professor Wayne S. Vucinich, edited by Ivo Banac, John G. Ackerman, Roman Szporluk, 35-59. New York: East European Monographs and Columbia University Press, 1983.

Pappas, N. "Guerrilla Warfare in the Balkans, 1941-1945: A Historiographic Essay." In Papers of the U.S.M.A.- R.O.T.C. Military History Fellowship. West Point, NY: 
United States Military Academy, 1991.

Pappas, N. Greeks in Russian Military Service in the Late Eighteenth and Early Nineteenth Century. Thessalonike: Institute for Balkan Studies, 1991.

Pappas, N. "Greece and the Russian- Ottoman War of 1877-1878." In OttomanRussian War of 1877-1878. Ankara: Middle East Technical University Press, 2006.

Pappas, N. "Misinterpretations and Miscalculations of Contemporary Reports on the Balkan Wars." The Centenary of the Balkan Wars (1912-1913): Contested Stances, vol. 1 Ankara, Turkey: Turkish Historical Society, 2015.

Ramphos, K. Ta ten Helleniken Legeona tou Autokratoros Nikolaou A' ten kata to 1853 en Moldovlachia systetheisan aphoronta. Athens: Demetrios Syllivriotes, 1867.

Rodakes, P. Klephtes kai Armatoloi. Athens: Atermon, 1975.

Saloutos, T. The Greeks in the United States. Cambridge, MA: Harvard University Press, 1964.

Seizanes, M. He Politike tes Hellados kai he epanastasis tou 1878 en Makedonia. Athens, 1878.

Todorova, M. "Greek Volunteers in the Crimean War." Balkan Studies, no. 25(1984): 539-563.

Vakalopoulos, A. Ta Hellenika Strateumata tou 1821: organose, ege sia, taktike, ethe, psychologia. Thessalonike: Hellenike Iatrike, 1948.

Vakalopoulos, A. "Nea stoicheia gia tois epanastaseis tou 1821 kai tou 1854 ste Makedonia." Epistemonike Epeteris Philosophikes Scholes tou Aristoleiou Panepistemiou Thessalonikes, no. 8(1956): 63-103;

Vasdravelles, I. "He epanastasis tou 1854 eis ten Chalkidiken Chersoneson." Makedonika no. 5(1961-1963): 102-124.

Venteres, G. He Hellas tou 1910-1920, vol. 1. Athen: Pyrsos, 1931.

Veremis, T. "Kapodistrias and the French: The Formation of the Greek Regular Army." In East-Central European Society and War in the Era of Revolutions, 1775-1856, edited by B. Király, 256-270. New York, 1984.

Vournas, T. To Goudi. To Kinema tou 1909. Athens: Techne-Episteme, 1957.

Vyzantios, C. Historia ton kata ten Helleniken Epanastasin ekstrateion kai machon on symmeteschen ho taktikos stratos apo to 1821 mechri tou 1832. Athens: K. Ralles, 1837. 